\title{
Desain konsep kendaraan roadster tahun 2050 yang menerapkan teknologi turbine engine
}

\author{
Geggy Gamal S., ${ }^{*}$ Khaola Rachma Adzima ${ }^{1}$ \\ ${ }^{1}$ Universitas Esa Unggul, Jakarta, Indonesia
}

\begin{abstract}
The design in the next 30 to 100 years is a vision of industrial desainers to be able to provide an overview or exposure to the government, companies, industry players and the public, how this future product is projected (pictured) into a mature mind and can be realized according to provisions in his time. This depiction needs to be exploited through design education science. Without the knowledge of design education, thinking in this design cannot be described. Describe what is meant is "design process". Methods Research in the concept vehicle design uses qualitative methods and uses analysis and design that includes background, issue, problem solving, purpose and benefits of design, concept design, image board, image chart, mood board, keyvisual, keyword, brainstorming sketches, developing sketches, detailing sketches, final sketches, Computer Aided Industrial Design (3D Design), and final 3D. Conclusions from the results of designing future vehicle concepts can be continued as a result of further research in the role of scientific design in industrial design and transportation. The ability of Indonesian desainers, especially in the field of industry and transportation, has been able to move internationally as desainers of international-level vehicles.
\end{abstract}

Key words: transportation design, vehicle design, vehicle concept

\begin{abstract}
Abstrak
Perancangan dalam 30 sampai dengan 100 tahun kedepan adalah sebuah visi para desainer industri agar dapat memberikan sebuah gambaran atau paparan kepada pemerintah, perusahaan, pelaku industri dan masyarakat, bagaimana sebuah produk masa depan ini diproyeksikan (tergambarkan) menjadi sebuah pemikiran yang matang dan dapat masuk diakal sesuai bekal pada zamannya. Penggambaran ini perlu dieksploitasikan melalui keilmuan pendidikan desain. Tanpa adanya keilmuan pendidikan desain, pemikiran dalam perancangan ini tidak dapat diuraikan. Uraikan yang dimaksudkan adalah "design process”. MetodePenelitian dalam rancangan kendaraan konsep menggunakan metode kualitatif dan menggunakan analisis dan desain yang mencangkup dari background, issue, problem solving, tujuan dan manfaat perancangan, design concept, image board, image chart, mood board, keyvisual, keyword, brainstorming sketches, developing sketches, detailing sketches, final sketches, Computer Aided Industrial Design (3D Design), dan final 3D. Kesimpulan dari hasil perancangan konsep kendaraan masa depan dapat dilanjutkan sebagai hasil penelitian lanjutan dalam peran pendidikan keilmuan desain industri dan transportasi. Kemampuan desainer Indonesia khususnya dibidang industri dan transportasi sudah mampu bergerak di kalangan internasional sebagai perancang kendaraan yang berkonsep taraf internasional.
\end{abstract}

Kata kunci: desain transportasi, desain kendaraan, kendaraan konsep

\section{Pendahuluan}

Transportasi darat pada masa mendatang adalah sesuatu yang merupakan hal baru. Masa sekarang, transportasi darat yang ada di benak manusia mungkin salah satunya adalah mobil, motor, sepeda, kereta api, MRT, LRT, bus, dll. Bagaimana dengan transportasi yang belum terpikirkan oleh manusia? tentu ada. Hal tersebut ditentukan dengan 'design concept'. Design concept adalah suatu gambaran atau rancangan yang diciptakan dan dibuat berdasarkan hasil pemikiran yang matang dan terkonsep. Tiap perancang/desainer selalu memiliki ide atau pemikiran-pemikiran yang melangkah maju ke depan guna agar bermanfaat untuk manusia kedepannya dan memiliki visi misi

\footnotetext{
* Corresponding author e-mail : geggy.gs@esaunggul.ac.id
} 
yang masih fresh atau sesuatu yang baru (new design or blue ocean strategy). Desain konsep kendaraan roadster tahun 2050 berbasis visi dan misi peneliti yaitu dalam bidang desain industri dan desain transportasi. Sesungguhnya konsep desain ini membicarakan tentang pandangan transportasi pada tahun 2050, di mana pada tahun tersebut diprediksi akan bermunculan kendaraan-kendaraan baru dengan gaya konsep yang baru yang manusia saat sekarang belum bisa menerkanya walaupun pada tahun sekarang (2017) sudah bermunculan kendaraankendaraan konsep yang digambarkan yang benarbenar baru seperti hyper loop, airbus vehicle, dan lain sebagainya, bahkan akan dibuat realisasinya dalam beberapa tahun ke depan. Dengan begitu, visi dan misi sang desainer dan peneliti memiliki wawasan yang unik dan kreatif pada masa mendatang guna mempercepat desain-desain tersebut terealisasi. Berdasarkan latar belakang yang dijelaskan di atas, maka studi penelitian tentang Kajian ini lebih berdasarkan design by research. Ide dan desain tentu mudah untuk dicuri. Itulah mengapa suatu ide yang cemerlang dan desain konsep yang unik begitu mahal harganya. Penemuan desain seperti ini perlu diakui konsep ide dan desainnya di Indonesia. Bahwa orang Indonesia mampu menciptakan ide-ide yang tidak kalah oleh desainer-desainer barat. Negara Indonesia mampu bersaing dengan Negara yang maju dalam hal ide dan konsep baru. Tidak sekedar ide maupun konsep baru, ilmu desainer Indonesia mampu bersaing bahkan sejajar dengan negara produsen pencipta kendaraan konsep dalam ilmu proses desainnya (design process knowledge). Proses desain itu mulai dari tarik garis (sketsa) sampai bentuk jadi (mock-up). Design process ini akan dijelaskan dalam penelitian ini, bagaimana langkah awal dalam membuat sampai bentuk jadi, diantaranya akan dijelaskan sebagai berikut. Fase I: Konsep pemikiran/ide yang berupa latar background, problem solving, purpose and benefit, roadmap/time frames, aspek ekonomi, aspek lingkungan, aspek sosial dan budaya. Fase II: Design Concept, brainstorming sketches idea, developing sketches, detailing sketches, alternative sketches, final sketches, sketches to $3 D, 3 D$ modeling, $3 D$ detailing, $3 D$ final modeling, $3 D$ rendering, $3 D$ alternative color rendering, dan $3 D$ diorama. Fase III: Tape drawing model, rekayasa model dan $3 D$ print model. Dengan adanya proses fase ini, maka penelitian ini dapat terbuka untuk penelitian lanjutan yang ingin melanjutkan penelitian yang berdasarkan dari pemikiran ide orang Indonesia dan dapat dikembangkan desain tersebut dalam masa mendatang. Tujuan Khususnya adalah Memberi kesadaran pada pemerintahan Indonesia dan perusahaan besar Indonesia bidang desain dan pengembangan (research \& development) khususnya dalam sektor infrastruktur transportasi agar membuka mata bahwa Indonesia memiliki pemikiran-pemikiran ide konsep baru yang tidak kalah dengan pemikiranpemikiran ide konsep orang barat. Dengan melihat proses desain yang menakjubkan disini, orang awam pun akan memahami proses desain yang dilakukan di dunia barat dalam ilmu desain industri (industrial design) dan ilmu desain transportasi (transportation design). Keutamaan penelitian ini adalah memberi pandangan tentang kendaraan tahun 2050 dengan konsep desain baru yang digabungkan dengan ide teknologi tanpa sumber daya alam (minyak, listrik, dll), yaitu sistem magnet yang masih diteliti hingga sekarang sehingga penerapannya sinkron dengan penelitian perancangan ini. Pertegasan penelitian ini adalah merancang kendaraan konsep baru untuk tahun 2050 dengan teknologi yang masih diteliti saat ini, digabungkan dengan proses desain yang menawan dan mudah dimengerti dalam masyarakat, peneliti, desainer dan pemerintah Indonesia yang ingin mengelola infrastruktur transportasi dengan ide orang Indonesia. Ilmu desain produk/desain industri dan desain transportasi masih minim dan awam di Indonesia bahkan para pakar professional dibidang ini pun masih sedikit di Indonesia, maka dari itu dengan penjelasan disini tidak menutup kemungkinan agar masyarakat dan pemerintah di Indonesia tertarik akan ilmu bidang desain transportasi dan dapat diaplikasikannya di kemudian hari. Penelitian ini mengharapkan ke depannya memiliki terobosanterobosan baru (konsep baru dan pandangan baru) guna mengatasi minimnya atau sedikitnya yang mempelajari ilmu desain transportasi yang menekankan terhadap proses desain. Penelitian perancangan ini mengajukan keutamaan sebagai berikut:

Penelitian perancangan ini melahirkan suatu wawasan ide yang post-modern untuk membantu kualitas pemikiran konsep masyarakat, peneliti, desainer dan pemerintah yang bergerak dibidang ini. Penelitian ini akan memperlihatkan gambaran kendaraan dalam sajian visi post-modern (berupa diorama, hasil rendering, panorama realistic render) dan dapat disentuh oleh kulit (hasil $3 D$ print dan mock-up) dengan merasakan bentuk fisiknya (dalam bentuk skala).

\section{Bahan dan Metode}

Mobil konsep adalah sebagai kendaraan "bintang ternama” dalam dunia otomotif. Mereka cemerlang 
tetapi terlalu singkat sebelum menghilang begitu saja. Namun dalam beberapa ide konsep itu, mereka mengejutkan, mengagetkan, menerangi dan mengilhami. Berikut adalah contoh-contoh gambar desain konsep kendaraan masa depan :

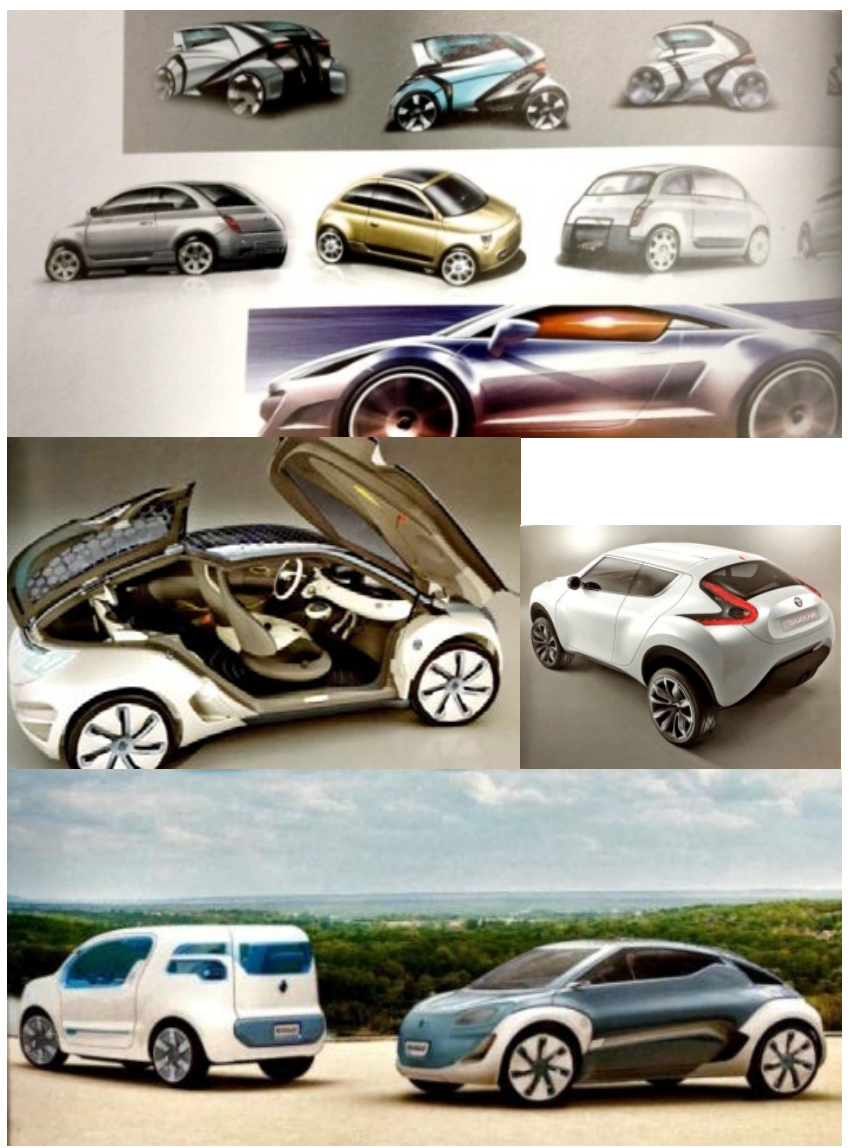

Gambar 1. Sketsa desain kendaraan konsep (Sumber: Tony Lewin dan Ryan Borrof, 2010)

Apa itu desain otomotif? Sederhana, itu adalah sebuah pengembangan nilai estetika dari setiap elemen mobil yang dapat dilihat oleh konsumen. secara historis, pengembangan dalam sarana desain otomotif disebut sebagai juga "styling". Namun pada abad ke-21 tampaknya 'kuno' untuk menunjukkan bahwa desain otomotif adalah pertimbangan semata dalam bentuk estetika, gaya visual kendaraan untuk menarik konsumen ketika latar belakang yang dibuat mobil sangat kompleks. Desain mobil adalah desain yang rumit, semakin modern. Bahkan dengan pengenalan teknologi desain digital dan virtual, yang memiliki potensi untuk memudahkan dan mempercepat proses desain, meningkatnya tuntutan keamanan, teknik, keselamatan, dan peraturan lingkungan, dan tuntutan undang-undang yang selalu berubah-ubah, berarti bahwa otomotif saat ini desainer harus mempertimbangkan dan mengakomodasi sejumlah kendala potensi desain. Paling tidak, desain harus mencapai standar yang semakin tinggi untuk menjadi sukses. Terlebih lagi, untuk melakukannya, desainer harus menjadi komunikator yang sangat baik untuk menyampaikan niat desain mereka ke disiplin internal lainnya, termasuk pemasaran, teknik, dan keselamatan. Hal ini sangat menantang ketika anda mempertimbangkan bahwa desain mobil terbaik adalah yang paling sulit untuk dihargai, terutama oleh non-desainer. Hal ini juga berlaku ketika lampu hijau diberikan, proses desain dapat menggabungkan lusinan individu semua bekerja sama untuk menciptakan produk otomotif tunggal. Komunikasi yang efektif tetap menjadi kunci di sepanjang proses desain agar berhasil mengarahkan evolusi produk kendaraan melalui proses yang harus memperhitungkan berbagai pengaruh, semuanya berdampak pada desain akhir (Tony Lewin, 2010:74). Dijelaskan oleh Tony Lewin dan Ryan Borrof (2010:75) bahwa desainer harus memiliki komunikasi yang bagus dalam menyampaikan maksud desain mereka kepada seseorang pada bidang lainnya, termasuk dalam ilmu marketing, ilmu teknik dan faktor keselamatan. Desainer harus mempunyai ilmu desain marketing, engineering dan safety factor. Dalam perancangan ini, faktor yang harus diperhatikan dalam mendesain adalah branding kendaraan tersebut, fungsi, efektifitas (usability), faktor keamanan (pemakai dan diluar pemakai), keamanan kendaraan, dan faktor engineering (biaya, material, dll). Serta harus melihat dalam aspek lingkungannya. Tahapan design process-nya adalah sebagai berikut: Stage 1, Early specification: pada tahap awal ini biasanya dimulai dari ide konsep yang ada, mulai dari latar belakang, specs, analisis, image board, image chart, moodboard, styling image, key visual, dll. Stage 2, Generation of early concept sketches, yaitu menggunakan gambar sebagai media bentuk. Media bentuk tercipta dari sketsa. Sketsa bisa berupa manual drawing sampai kepada digital drawing. Manual drawing biasanya para desainer menggunakan pensil, pulpen, penggaris mal, marker, dll. Untuk digital drawing, desainer biasa menggunakan produk wacom ${ }^{\mathrm{TM}}$ atau sejenisnya. Stage 3, Design shortlist: Setelah ditentukan hasil gambarnya, maka akan ada gambar pengembangan dan gambar-gambar hasil detail. Kemungkinan akan ada gambar-gambar alternatif model eksterior, interior dan gambar perspektif dari segala sudut. Agar mudah dibaca atau diskemakan ke dalam CAD (Computer Aided Design) seperti Autodesk Alias. Stage 4, Final shortlist and clay and digital modeling: Setelah terpilih hasil akhirnya, maka bentuk virtual 3D dan 
model tanah liat (clay model) mulai dikerjakan. 3D model akan mengevaluasi dari hasil desain tangan dari segala sudut, dapat dieksplor dan mudah untuk di rendering. Dalam model tanah liat, beda dengan 3D model yang hanya ada di dunia maya, model tanah liat terletak di dunia nyata dan dapat 'dirasakan' bentuknya dalam bentuk skala. Stage 5, Interior design: Desain interior dimulai begitu desain eksterior dikerjakan. Desain interior kendaraan biasanya lebih kompleks dari pada pengerjakan desain eksterior, karena lebih banyak sisi permukaan yang luas dan mengandung lebih banyak unsur material yang akan diaplikasikannya, serta melibatkan beberapa desainer interior dalam pengerjaannya (sebagai tim). Stage 6, Final model/prototype build: Setelah data 3D modelling, clay modelling dan data ukuran usai, maka part komponen kendaraan prototype dapat di produksi dan dibuat. Biasanya dilakukan di studio otomotif dalam ruangan yang besar dan tertutup. Stage 7, Feasibility: Apabila manajemen telah menyetujui hasil akhir, maka hasil skala 1:1 nya dari hasil tanah liat akan di scan untuk menciptakan 3D digital model dan akan digenerasikan ke data akhir agar bisa digunakan dan dibaca oleh pihak produksi (pabrik kendaraan) yang akan memproduksinya agar bisa membuat komponen-komponen dan part kendaraan konsep tersebut. Stage 8, Final approval: Penyetujuan hasil akhir prototype, akan diputuskan oleh pihak manajemen dalam memproduksinya. Hasil tersebut akan dievaluasi oleh tim manajemen dari hasil prototype yang akan dipamerkan di dalam studio otomotif. Tahapan Desain Proses dalam proyek desain ini, tahapan yang dilakukan hanya sampai kepada tahapan ke-5. Apabila dilanjutkan, finalisasi dilakukan sampai kepada tahapan ke-6 berupa skala 1:5 atau skala 1:10.
Tujuan utama untuk proyeknya telah ditetapkan. Ini harus dipertimbangkan baik dari sudut pandang konsumen maupun produsen. Design Package \& Ideation: tata letak dasar komponen utama dan setiap fitur inovatif dibuat sketsa secara bebas dalam berbagai konfigurasi. Benchmarking Sizing \& Proportions: Produk yang ada dengan atribut yang sama dicocokkan dengan memvalidasi arahan desain. Proses ini digunakan untuk menetapkan proporsi dasar. Advanced Design Packaging \& Clay Model Development: begitu dimensi dasar dan poin utamanya yang untuk konsep dirumuskan, skala atau model tanah liat ukuran penuh dibangun dan dikembangkan dengan balutan.

Menurut Tony Lewin (2010:162) banyak kemajuan besar dalam desain mobil dapat ditelusuri kembali ke model konsep visioner yang ditulis oleh desainer imajinatif. Beberapa dari mobil-mobil yang tampak ke depan ini sepenuhnya dipahami ketika pertama kali diperkenalkan; beberapa di antaranya bahkan disambut dengan syok atau bingung, tetapi semua akan terus memiliki pengaruh besar pada mobil yang kita beli dan kendarai. Hal ini menyatakan bahwa pada tahun 2050 tentu desain-desain pada kendaraan akan mengalami perubahan besar dalam aspek kemajuan. Desain otomotif butuh daya imajinatif dalam penciptaan desainnya. Modernisme adalah campuran antara nilai-nilai pencerahan dan tekanan yang diberikan oleh postmodernisme yang baru muncul pada usaha mencampur-adukkan gaya, kesadaran diri dan yang puitis. Modernisme sebagai gerakan meliputi kurun waktu dari kira-kira 1910 sampai pecahnya Perang Dunia II. Para modernis adalah murid sains, yang mengharapkan dunia yang kuat dan baru, serta menggunakan teknologi dan matematika dalam desain mereka.

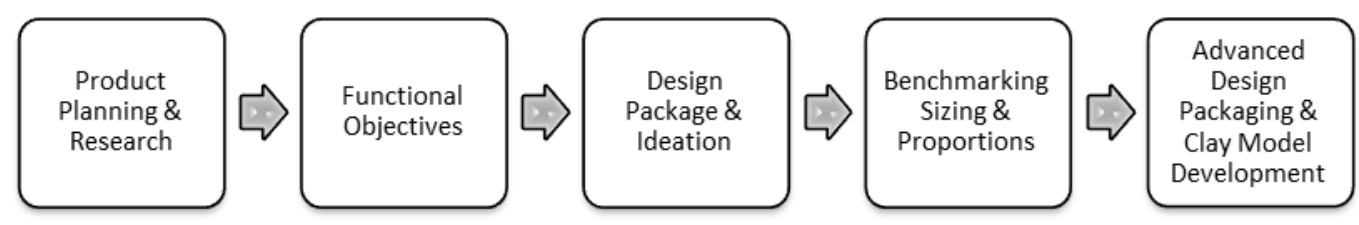

Gambar 2. Advanced Concept Design Process (Stuart Macey, 2009)

Stuart Macey (2009:22) menjelaskan dari tiap-tiap proses desain konsepnya sesuai Gambar 2 di atas, diantaranya; Product Planning \& Research: Prosesnya dimulai dari riset market yang diharapkan, konsumen dan persaingan. Strategi teknologi dan manufaktur yang sedang berkembang (yang baru) juga dipelajari dan dikaitkan. Functional Objectives:
Efek kegunaan estetika menggambarkan suatu fenomena di mana orang mempersepsikan desain yang lebih estetis dan lebih mudah digunakan daripada desain yang kurang berestetis. Efeknya telah diamati dalam beberapa percobaan, dan memiliki implikasi signifikan mengenai penerimaan, penggunaan, dan kinerja desain. Desain estetika 
terlihat lebih mudah digunakan dan memiliki kemungkinan yang lebih tinggi untuk digunakan, terlepas dari apakah itu sebenarnya lebih mudah digunakan. Desain yang memiliki manfaat tetapi kurang estetik mungkin akan mengalami kurangnya penerimaan yang menjadikan suatu masalah dalam penggunaan. Estetika memainkan peran penting dalam cara desain. Desain estetis lebih efektif dalam pengembangan sikap positif daripada desain yang tidak memiliki sifat estetis, dan membuat orang lebih toleran terhadap metode desain. Desain estetika dianggap lebih mudah digunakan, lebih mudah diterima dan digunakan dari waktu ke waktu, dan mempromosikan pemikiran kreatif dan pemecahan masalah. Sikap estetis juga menumbuhkan hubungan positif dengan orang-orang, membuat mereka lebih toleran terhadap masalah dengan desain (William Lidwell, 2010:20).

\section{Roadster}

Kendaraan Roadster pada umumnya adalah kendaraan yang ringan (lightweight) dalam bentuk sports-car tanpa memakai atap permanen. Atap tersebut bisa dibuka dan ditutup (dalam bentuk hardtop maupun softtop). Contohnya dalam bentuk kendaraan Lotus Elan tahun 1962 yang diciptakan oleh sang desainer yang bernama Colin Chapman. Kendaraan tersebut dinamai "the british roadster", memiliki berat kendaraan $590 \mathrm{~kg}$ dengan panjang wheelbase $2135 \mathrm{~mm}$. Kendaraan roadster saat sekarang banyak memakai filosofinya Lotus Elan dalam ukuran tersebut. Tapi Stuart Macey (2008:17) menyatakan bahwa roadster ke depannya bisa saja bentuknya agak besar khususnya dalam penambahan daya tampung penumpang, kapasitas mesin dengan torsi besar dan keamanan tinggi dalam struktur bodi kendaraan.

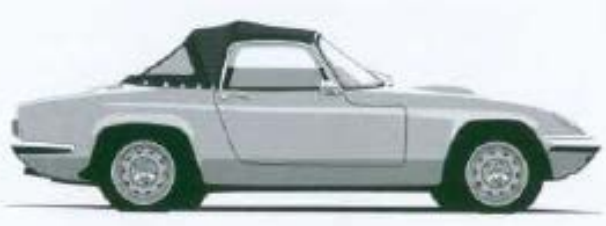

1962

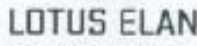

[ENGLAND]

Gambar 3. British Roadster

(Sumber: Stuart Macey, 2008)
Pada tahun 2009, BMW menciptakan sebuah kendaraan roadster dengan atap permanen dengan teknologi tinggi serta mengaplikasikan desain kendaraan masa depan yang ditarik (bentuk konsepnya) pada masa sekarang, yaitu BMW Vision EfficientDynamics. BMW Vision EfficientDynamics adalah kendaraan yang sangat efisien, menggabungkan kinerja model BMW $\mathrm{M}$ dengan konsumsi bahan bakar dan emisi mobil kecil modern. Ini adalah kendaraan yang hampir siap produksi dengan konsep rekayasa terpadu yang menampilkan teknologi ActiveHybrid dan membawa BMW EfficientDynamics ke level berikutnya. Mobil konsep BMW Vision EfficientDynamics adalah plug-in hybrid dengan mesin turbo diesel tiga silinder. Selain itu, ada dua motor listrik dengan 139 daya kuda. Hal ini memungkinkan percepatan hingga $100 \mathrm{~km} / \mathrm{jam}$ dalam 4,8 detik dan kecepatan tertinggi secara elektronik $250 \mathrm{~km} / \mathrm{jam}$. Menurut BMW, konsumsi bahan bakar rata-rata dalam siklus pengujian Uni Eropa adalah 3,76 liter /100 kilometer dan memiliki peringkat emisi karbon dioksida 99 gram per kilometer. Perkiraan semua rentang listrik adalah 50 $\mathrm{km}$ dan tangki bensin 24 liter memperluas jangkauan kendaraan total hingga $700 \mathrm{~km}$. Sasis ringan dibuat terutama dari aluminium. Kaca depan, atas, pintu dan spatbor terbuat dari kaca polikarbonat. Perancang konsep BMW Vision EfficientDynamics adalah Mario Majdandzic untuk eksterior dan Jochen Paesen untuk interior. Kendaraan ini adalah sebagai pembuka kendaraan masa depan yang diaplikasikan pada masa sekarang.

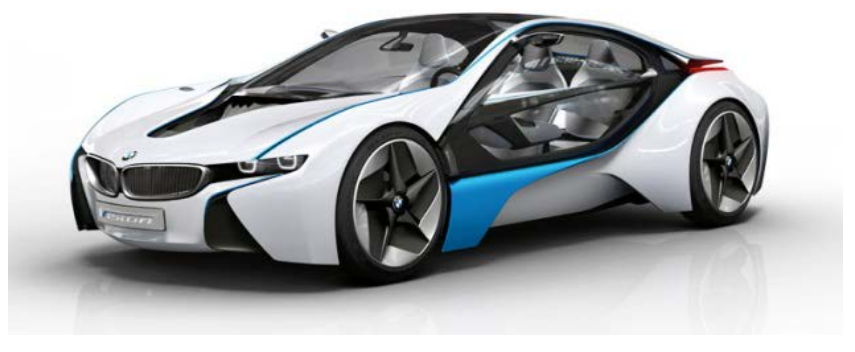

Gambar 4. Roadster BMW Vision EfficientDynamics (Sumber: http://www.aucklandcitybmw.com)

Dalam sejarah pertumbuhan transportasi, Sejak dahulu kala transportasi telah digunakan dalam kehidupan bermasyarakat. Sebelum tahun 1800 alat pengangkutan yang digunakan adalah tenaga manusia, hewan dan sumber tenaga dari alam. Antara tahun 1800-1860 transportasi telah mulai berkembang dengan dimanfaatkannya sumber tenaga mekanis 
seperti kapal uap, kereta api, dan sejenisnya pada tahun tersebut. Pada tahun 1860-1920 telah ditemukan kendaraan bermotor pesawat terbang, kendaraan roda dua dan kendaraan roda empat. Dalam tahun 1920 transportasi telah mencapai tingkat perkembangan pada puncaknya (mature), dengan sistem transportasi multi modal (multi modal systems). Dalam abad ke-20 ini pertumbuhan transportasi berkembang pesat sejalan dengan kemajuan teknologi mutakhir (Salim, 2012). Transportasi sebagai dasar untuk pembangunan ekonomi dan perkembangan masyarakat serta pertumbuhan industrialisasi. Dengan adanya transportasi menyebabkan, adanya spesialisasi atau pembagian pekerjaan menurut keahlian sesuai dengan budaya, adat-istiadat, dan budaya suatu bangsa atau daerah. Pertumbuhan ekonomi suatu negara atau bangsa tergantung pada tersedianya pengangkutan dalam negara atau bangsa yang bersangkutan. Dalam transportasi kita melihat dua kategori, yaitu: (1) Pemindahan bahan-bahan dan hasil-hasil produksi dengan menggunakan alat angkut; dan (2) Mengangkut penumpang dari suatu tempat ke tempat lain.

Guna mempelajari transportasi secara mendalam, perlu diketahui makna dari sistem transportasi (transportation systems). Dengan ini dapat disimpulkan bahwa definisi transportasi adalah kegiatan pemindahan barang (muatan) dan penumpang dari suatu tempat ke tempat lain. Dua unsur terpenting yaitu berupa pemindahan/pergerakan (movement) dan secara fisik mengubah tempat dari barang (komoditi) dan penumpang ke tempat lain (Salim, 2012). Dalam teori emotional design, kemajuan teknologi pada saat ini membuat produk menjadi lebih murah dan massal, dengan keberagaman variasi yang hampir serupa. Dengan hal seperti ini akan mudah membuat seseorang mencapai titik jenuh terhadap produk yang tidak ada variannya. Dan akhirnya konsumen mengalami perubahan sikap dan persepsi pada produk, yaitu mereka mencari produk yang memiliki nilai emosi pada masingmasing kepribadiannya. Pendekatan emotional design adalah desain dengan memperhatikan tanggapan emosional konsumen pada perancangan produk. Faktor emosi dijadikan nilai tambah yang menjadi pembeda antara produk-produk yang memiliki fungsi yang sama (Gumulya, 2015:1). Hal ini mendukung dalam penciptaan desain yang dibaluti dengan teknologi penggerak kendaraan ini. Sedangkan dalam teori desain industri, John Heskett (1980:16) membicarakan tentang Henry Cole, ia pernah membuat jurnal desain. Bersama rekan-rekannya, Cole banyak menyumbangkan pendiriannya. Dalam jurnalnya menyatakan: "Desain memiliki dua pengertian yang berkaitan, pertama, mengacu pada kemanfaatan benda yang didesain. Kedua, memperindah dan menghiasi kemanfaatannya. Kata 'desain' lebih banyak berkenaan dengan pengertian yang kedua daripada dengan seluruh pengertiannya hiasan, sebagai bagian dari kemanfaatan, acapkali malah bertentangan dengan kemanfaatan itu sendiri. Maka yang mendasar dari pembauran yang hanya sebagai unsur tambahan, pembauran itu telah menimbulkan kekeliruan besar dalam hal selera (taste) yang bisa diamati pada karya-karya para desainer modern. John Heskett (1980:23) juga menjelaskan bahwa kebesaran John Ruskin, yang dalam ceramah-ceramahnya serta tulisan-tulisannya, menegaskan gagasan-gagasannya sejelas mungkin dengan suatu keyakinan yang bersifat ramalan masa datang (prophetic). Dalam sebuah artikel yang dipublisir pada tahun 1865 dalam jurnal seni berjudul 'the cestus of aglaia', ia mengajukan pertanyaan: "seberapa jauh kesenian murni bisa dengan baik menggantikan atau mengatur seni-seni mekanis?" Dibalik keraguan yang diajukannya, tersirat tentang jawaban yang ditawarkannya. Walaupun ia mengakui dengan "rasa takjub, keramaian yang bersahaja- pada saat memperhatikan lokomotif menarik nafas di stasiun kereta api". Dengan mengagumi presisi dan kemahiran mekaniknya, jelaslah produk-produk 'seni mekanik' itu tidak mempunyai tempat dalam filosofi estetik. Ia menyimpulkan : "benda yang menjerit itu, betapapun bagusnya dibuat, hanya dapat menarik atau mendorong, yang seharusnya dikerjakan sapi jantan dengan cara terpaksa". Dalam seluruh penyangkalannya bahwa produk-produk industri bisa memiliki nilai estetik, Ruskin merupakan pengejawantahan kekuatan elemen sosial dan ketegaran intelektual di Inggris yang menolak seluruh implikasi dari keluarbiasaan yang telah dihasilkan. Hal ini menunjukkan bahwa teori desain industri ini mengacu pada kendaraan otomotif yang pada zaman mendatang. Dan yang terakhir, yang menarik dari pembahasan John Heskett (1980:26) adalah tentang teori-teori Gottfried Semper, seorang arsitek Jerman, dalam sebuah tulisannya merumuskan teori-teori estetik yang mau tidak mau melibatkan kemajuan industrialisasi, serta menghadapkan permasalahanpermasalahan seni dan industri. Teori-teorinya didasarkan oleh pengkajian sejarah yang ekstensif, khususnya seni guna dan teknik-tekniknya. Pengkajian tersebut mengarahkannya pada suatu kesimpulan yang bertentangan dengan pemikiran akademis yang ada, bahwa gaya seni bukan percampuran dari berbagai wujud seni, melainkan 'peningkatan artistik dari kandungan ide dasar'. Tulisan-tulisan Semper membuka pengaruh baru dan 
juga memiliki dampak yang kuat di awal abad 20, yaitu pada saat muncul reaksi berlawanan terhadap kebangkitan gaya dan ornamentasi. Dalam rangka menelusuri bentuk-bentuk estetik dan alasan yang lebih kuat dan ekspresif bagi sifat teknologi di abad modern, banyak desainer beralih ke mesin, pirantipiranti dan juga produk-produk industri sebagai bentuk ungkapan dari teori-teori mereka. Pada tahun 1920-an lahirlah apa yang disebut dengan 'estetika mesin (machine aesthetic)', yang menitik-beratkan pada bentuk-bentuk geometris dan abstrak dan bertalian dengan filosofi fungsionalisme. Pembahasan dari teori Gottfried Semper dapat ditarik kesimpulan bahwa penelitian desain ini didukung oleh beliau dalam hal 'desain estetika'nya dalam konsep rancangan kendaraan tahun 2050. Konsep desain transportasi tahun 2050 lebih terjerumus ke dalam bentuk-bentuk yang mengutamakan aspek estetikanya.

Tujuan dari penelitian ini adalah untuk memberikan kesadaran pada pemerintahan Indonesia dan perusahaan besar Indonesia bidang desain dan pengembangan (research \& development) khususnya dalam sektor infrastruktur transportasi bahwa Indonesia memiliki pemikiran-pemikiran ide konsep baru yang tidak kalah dengan pemikiran-pemikiran ide konsep orang barat. Dengan melihat proses desain yang menakjubkan di sini, orang awam pun akan memahami proses desain yang dilakukan di dunia barat dalam ilmu desain industri (industrial design) dan ilmu desain transportasi (transportation design).

Keutamaan penelitian ini adalah memberi pandangan tentang kendaraan tahun 2050 dengan konsep desain baru yang digabungkan dengan ide teknologi tanpa sumber daya alam (minyak, listrik, dll), yaitu sistem magnet yang masih diteliti hingga sekarang sehingga penerapannya sinkron dengan penelitian perancangan ini. Pertegasan penelitian ini adalah merancang kendaraan konsep baru untuk tahun 2050 dengan teknologi yang masih diteliti saat ini, digabungkan dengan proses desain yang menawan dan mudah dimengerti dalam masyarakat, peneliti, desainer dan pemerintah Indonesia yang ingin mengelola infrastruktur transportasi dengan ide orang Indonesia. Ilmu desain produk/desain industri dan desain transportasi masih minim dan awam di Indonesia bahkan para pakar profesional di bidang ini pun masih sedikit di Indonesia, maka dari itu dengan penjelasan di sini tidak menutup kemungkinan agar masyarakat dan pemerintah di Indonesia tertarik akan ilmu bidang desain transportasi dan dapat diaplikasikannya di kemudian hari. Penelitian ini mengharapkan ke depannya memiliki terobosan- terobosan baru (konsep baru dan pandangan baru) guna mengatasi minimnya atau sedikitnya orang yang mempelajari ilmu desain transportasi yang menekankan terhadap proses desain. Penelitian perancangan ini mengajukan 2 keutamaan, yaitu: (1) Penelitian perancangan ini melahirkan suatu wawasan ide yang post-modern untuk membantu kualitas pemikiran konsep masyarakat, peneliti, desainer dan pemerintah yang bergerak di bidang ini; dan (2) Penelitian ini akan memperlihatkan gambaran kendaraan dalam sajian visi post-modern (berupa diorama, hasil rendering, panorama realistic render) dan dapat disentuh oleh kulit (hasil $3 D$ print dan mock-up) dengan merasakan bentuk fisiknya (dalam bentuk skala).

Metode yang digunakan dalam penelitian ini adalah metode studi literatur, yaitu studi berdasarkan hasilhasil penelitian sebelumnya guna pengumpulan data dan informasi untuk menjawab permasalahanpermasalahan yang ada dalam penelitian ini. Tahapan penelitian mengarah pada metodologi desain. Metoda ini disebut sebagai proses desain yang jelas, tepat dan mudah dimengerti. Unsur merancang sebuah kendaraan masa depan tetap berpedoman dalam ilmu desain industri, karena transportasi adalah bagian dari industri.

Objek yang diteliti adalah desain transportasi masa depan beserta teknologi yang dianutnya, yaitu teknologi turbin. Objek penelitian secara garis besar adalah prosesnya, yaitu proses desain (design process). Teknologi turbin hanya sebagai sekunder dalam pengaplikasiannya, sedangkan yang primer adalah desainnya.

Model penelitian ini menggunakan metodologi desain, yaitu merupakan sebuah pendekatan sains dari berbagai metoda yang dapat diterapkan dalam pemenuhan solusi sebuah desain. Desain tersebut dapat dikembangkan di kemudian hari sebagai hasil penelitian lanjutan yang ingin menempuh jalur desain industri khususnya di bidang desain transportasi. Sedangkan rancangan penelitian ini berdasarkan keilmuan desain industri dan desain transportasi. Rancangan penelitian yang dimaksud adalah "design process" atau proses desain yang akan dirincikan. Rincian tersebut adalah desain analisis yang terdiri dari aspek lingkungan, aspek ekonomi dan aspek sosial \& budaya, lalu Design Concept, Sketches, 3D Modeling with CAID (pemodelan 3 dimensi) dan 3D Rendering (penyataan model 3 dimensi). 


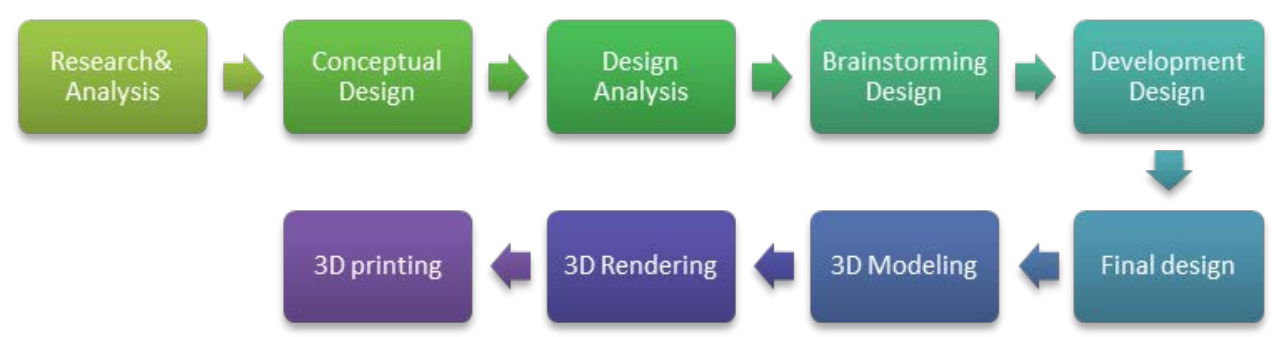

Gambar 5. Kerangka tahapan perancangan

\section{Hasil dan Pembahasan}

Aspek lingkungan pada tahun 2050 akan mengalami kemajuan dari sektor pembangunan dan infrastruktur. Tentu pada saat itu keadaan kota jauh lebih bersih berkat teknologi pada tahun tersebut. Lingkungan seperti ini terwujud berkat dukungan kinerja transportasi yang ramah lingkungan. Sedangkan aspek ekonomi pada tahun 2050 cenderung stabil. Tapi dalam 30 tahun mendatang tentu seluruh harga-harga tidak sama lagi seperti tahun sekarang, dengan alasan adanya laju inflasi yang naik-turun. Kestabilan ekonomi pada tahun tersebut diharapkan seimbang agar tidak melesui perbisnisan transportasi. Aspek sosial dan budayanya bertoleransi, saling membantu, ramah dan tamah. Seiring berkembangnya populasi dan pertumbuhan manusia, maka sosial dan budaya sudah ditanamkan sejak dini dalam dunia pendidikan tahun 2050.

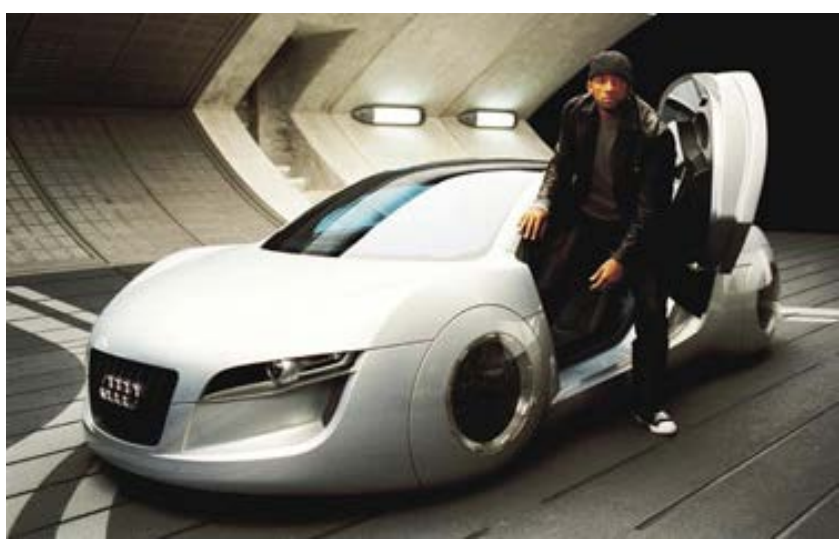

Gambar 6. Audi RSQ dalam film I Robot

Dalam pembahasan design concept, konsep kendaraan roadster untuk tahun 2050 terinspirasi dari kendaraan film "I Robot" yang diperankan Will Smith. Kendaraan yang dimaksud adalah Audi RSQ yang memakai hover wheels atau baller wheels.
Teknologi itu dipakai dalam tahun 2035 (dalam tema filmnya) yang menghapuskan teknologi tire wheels, di mana tahun 2035 berarti sudah mendukung teknologi yang menggantikan posisi ban roda kendaraan darat. Maka dari itu, konsep penerapan turbine engine wheels dapat didukung pada tahun 2050. Jenis wheels ini merupakan tandingan dari jenis wheels baller dan wheels hover.

\section{Desain Sketsa}

Industrial design adalah sebuah ilmu desain yang merancang sebuah produk melalui sketsa/gambar yang ditumpahkan dari ide seseorang yang kreatif ke dalam kertas gambar. Ilmu inipun memiliki gaya gambar tersendiri, yaitu industrial sketches.

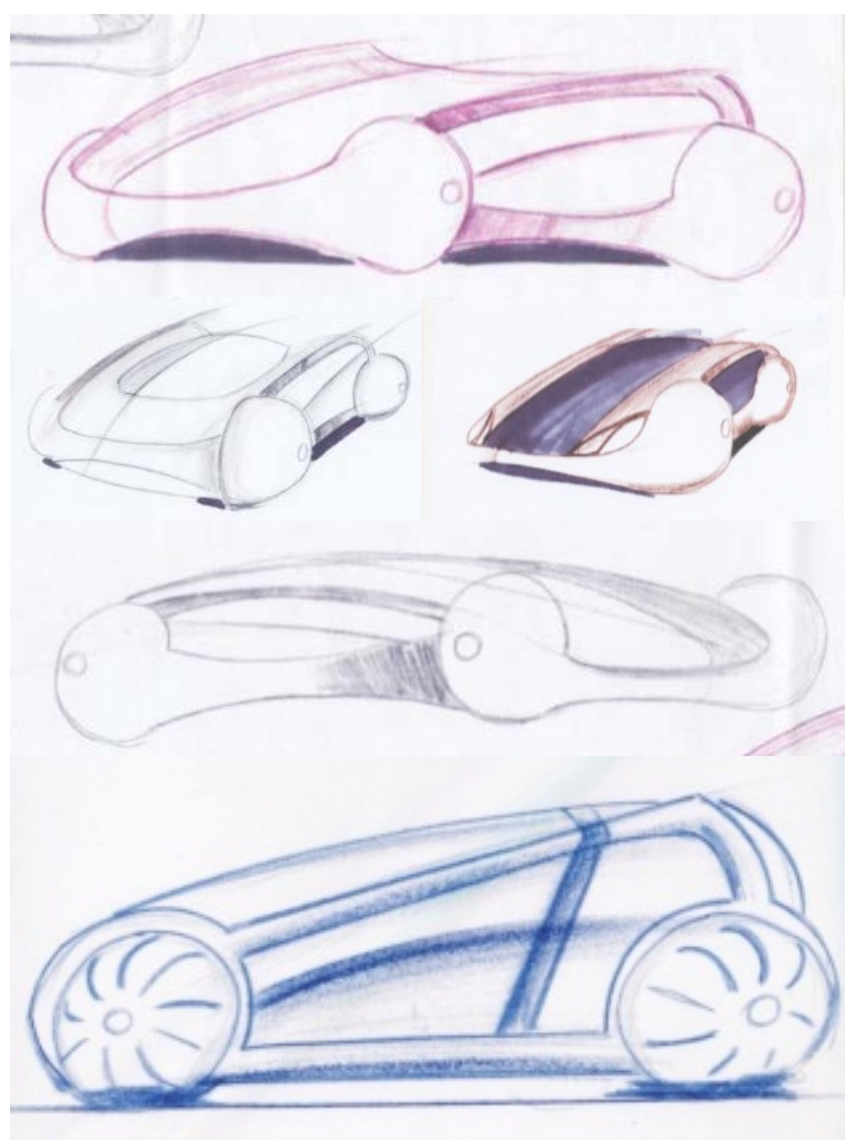

Gambar 7. Sketsa pengembangan 
Apa itu industrial sketches? Sketsa industri adalah sketsa yang memiliki garis-garis perspektif dengan adanya informasi grafis atau penjelasan detail melalui tulisan di atas gambar tersebut. Melalui sketsa industri, desain transportasi merupakan pengembangan darinya. Gambar 7 memperlihatkan desain pembentukkan roadster 2050.

Dari pencarian bentuk desain roadster 2050, maka telah ditentukan hasil sketsa akhirnya dibawah ini. Bentuknya lebih compact dan ringan sebagaimana roadster itu adalah kendaraan yang light-weight. Desainnya lebih mementingkan material kaca yang dipadukan dengan material plat (Gambar 8).

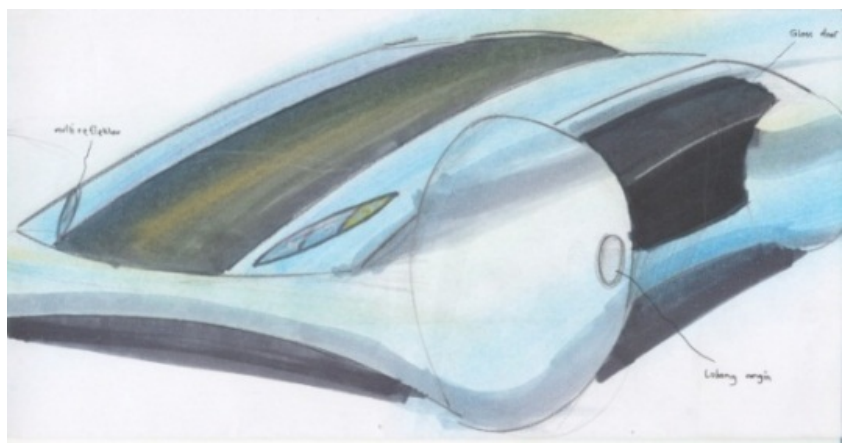

Gambar 8. Detail keseluruhan hasil sketsa akhir

\section{D Modelling with CAID (pemodelan 3 dimensi)}

Sketsa diwajibkan ditumpahkan ke dalam bentuk maya yaitu 3D modelling. Dengan bentuk pemodelan 3 dimensi, maka mudah dilihat dari segala sudut dan dapat dievaluasi dalam bentuk 3 dimensi. 3D modelling yang sangat ternama dan dipakai di studiostudio otomotif adalah software Autodesk Alias Autostudio. Software tersebut sudah terkenal dalam dunia desain transportasi dan desain industri. Berikut adalah hasil 3 dimensi dari Autodesk Alias Autostudio (Gambar 9).

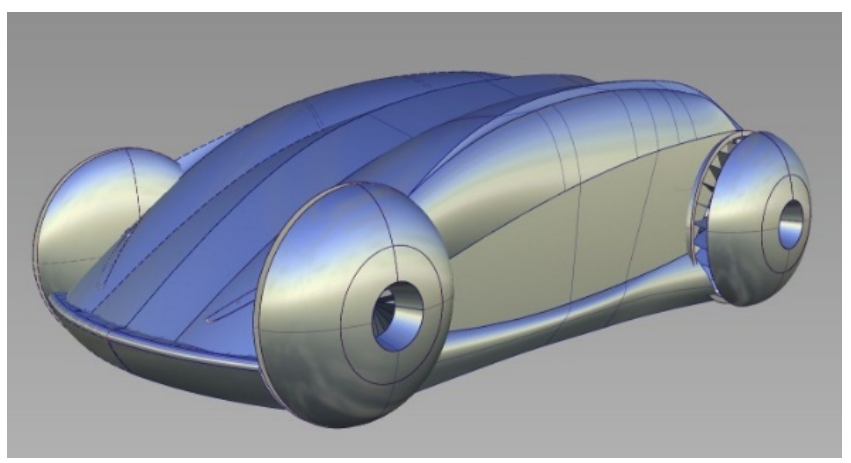

Gambar 9. Perspektif depan kiri

\section{D Rendering (penyataan model 3 dimensi)}

Agar bisa dibuat dalam bentuk realistik, maka dibutuhkan hasil desain yang memukau dari segi visualnya, yaitu 3D rendering dengan memakai software Keyshot. Sehingga terciptalah sebuah kendaraan roadster tahun 2050 yang menerapkan sistem turbine engine.

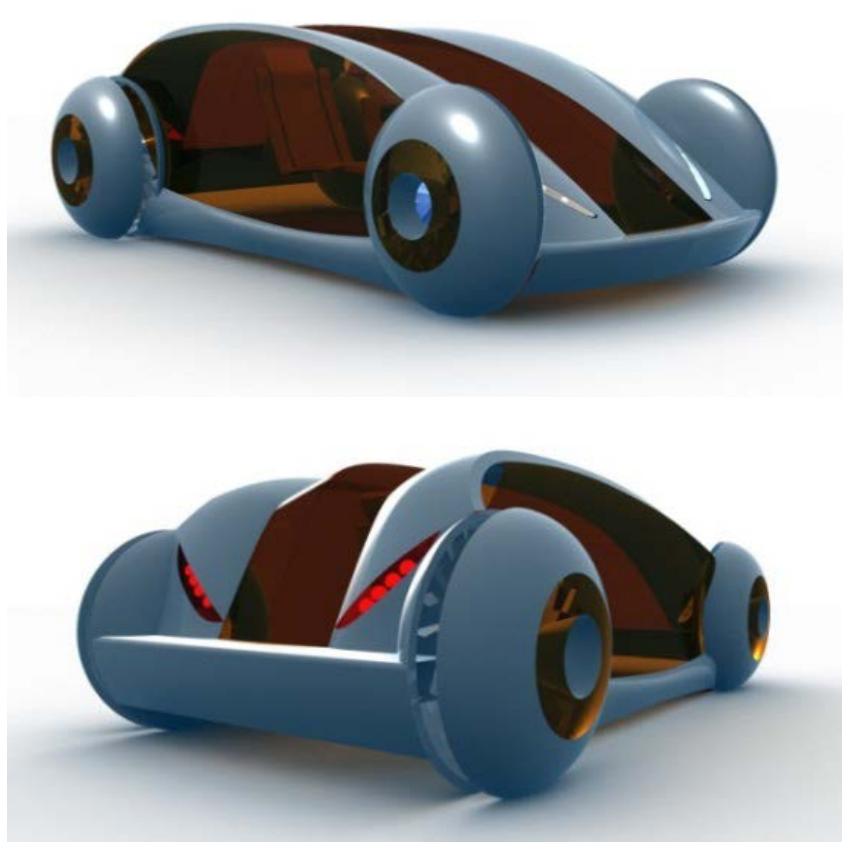

Gambar 10. Roadster 2050 with turbine engine wheel

\section{Kesimpulan}

Desain roadster 2050 ini diciptakan karena sebuah imajinasi masa depan. Melihat film dari "I Robot" yang diperankan Will Smith adalah sebuah film imajinasi masa depan yang memungkinkan teknologi itu akan terjadi/terealisasi. Teknologi yang dimaksud adalah kendaraan konsep yang dipakai dalam film tersebut. Dengan adanya penelitian ini, maka ide imajinasi tidaklah cukup tanpa didukung dengan ilmu desain industri dan desain transportasi yang telah diterapkan dan dijelaskan di sini. Diharapkan penelitian ini dapat dilanjutkan oleh peneliti lainnya yang akan menerapkan roda turbin ini dalam hal pergantian teknologi roda ban yang digunakan kurang lebih dari 1 abad. Tahun 2050 adalah tahun di mana yang akan mendukung teknologi ini mengingat teknologi semakin hari semakin maju dan tidak bisa dihindarkan. 


\section{Daftar pustaka}

Gumulya, D. (2015) Kajian teori emotional design. Jurnal Desain Volume 03 (01), 1-20

Heskett, J. (1986) Desain Industri, Bandung: CV Rajawali

Lewin, Tony \& Borrof, Ryan (2010) How to Design Cars Like a Pro, Minneapolis: MBI Publishing Company

Lidwell, W., Holden, K., \& Butler, J. (2010) Universal Principles of Design, Massachusetts: Rockport Publishers.

Macey, Stuart (2009) H-point: Fundamentals of Car Design \& packaging, Pasadena: Design Studio Press

O’Donnell, Kevin, (2003) Postmodernisme, Oxford: Lion Publising

Susantono, Bambang (2013) Transportasi dan Investasi: Tantangan dan Perspektif Multidimensi, Jakarta: PT Kompas Media Nusantara

Salim, A. (2012) Manajemen Transportasi, Jakarta: Rajawali Pres 